\title{
ORGANIZUOTOS VEIKLOS, TAIKANT DAILĖS TERAPIJOS ELEMENTUS, NAUDINGUMAS PARKINSONO LIGA SERGANTIEMS ASMENIMS
}

\author{
Aušra Kavaliauskienė, Ilona Venckienė \\ Kauno kolegijos Medicinos fakultetas
}

Raktažodžiai: Parkinsono liga, veikla, dailès terapija, identitetas, igalinimas, naudingumas, laisvalaikio veikla.

\begin{abstract}
Santrauka
Parkinsono liga - tai lètinè, progresuojanti liga, kuri anksčiau ar vèliau sutrikdo kasdieninę gyvenimo veiklą ir sukelia neigalumą. Asmenys, sergantys Parkinsono liga, dažniausiai netenka darbinès veiklos ir jiems ypač svarbi rūpinimosi savimi ir laisvalaikio veikla. Organizacijos, jungiančios tam tikra liga sergančius žmones, pasiūlo jiems veiklas, suteikiančias galimybę pažinti save, ligą, plèsti socialinius ryšius, geriau pažinti, realizuoti kūrybinius sumanymus. Straipsnio tikslas - atskleisti organizuotos veiklos, taikant dailès terapijos elementus, naudingumą Parkinsono liga sergantiems asmenims. Fenomenologinis kokybinis tyrimas atliktas 2017 sausio - vasario mèn., jame dalyvavo 23 asmenys iš Kauno apskrities Parkinsono draugijos Kauno skyriaus. Tyrimo rezultatai atskleide, kad organizuota veikla, taikant dailès terapijos elementus, sudaro galimybes Parkinsono liga sergantiems asmenims atrasti, plètoti ir stiprinti savo identitetą per gilesnị savęs bei kitu pažinimą ir į(si)galinimą. Sutvirtejjęs/suformuotas identitetas leidžia asmeniui pasijausti vertingu grupès nariu bei padidina igalinimo tikimybę. Tyrimo duomenų analizè parodè, kad organizuotos grupès nariams labai svarbus buvimo grupeje bendrumas, tačiau tuo tarpu kiekvienas grupès narys yra unikalus savo gyvenimo istorija. Bendros veiklos sèkmei labai svarbus kiekvieno grupès nario individualumo prièmimas. Atlikto tyrimo duomenimis, organizuotos veiklos, taikant dailès terapijos elementus, naudingumas pasireiškè šiose srityse: pasitikejjimo augimo, iggalinimo (įsigalinimo), socialinių ryšiu kūimo ir plètojimo, dienos struktūros formavimo bei prasmingo laiko leidimo, teigiamų emocijų patyrimo, naujovių
\end{abstract}

išbandymo saugioje aplinkoje, pozityvaus požiūrio skatinimo, bendros grupès istorijos kūrimo. Ypatinga organizuotos veiklos nauda reiškèsi kūrybiškai išbandant naujas veiklas saugioje aplinkoje bei bendros grupès istorijos kūrimo procese.

\section{İvadas}

Parkinsono liga - tai neurodegeneracinè liga, kurios metu pažeidžiami dopominerginiai, cholinerginiai, serotoninerginiai neuronai ir jų tarpusavio ryšiai. Parkinsono ligos diagnozè yra klinikinè, ji nustatoma remiantis paciento nusiskundimais, ligos anamneze ir klinikinio tyrimo duomenimis [8]. Mokslinès literatūros duomenimis, vyrai Parkinsono liga serga dažniau, dažniausiai susergama šeštajame - septintajame gyvenimo dešimtmetyje, bet pastebima ligos jaunèjimo tendencija. Lietuvoje Parkinsono liga serga per 12000 žmonių [10].

Gyvenimo pokyčiai, sergant lètine liga, stipriai paveikia asmens tapatumą ir gyvenimo būdą bei kelia sumaištị tiek vidiniame, tiek išoriniame asmens gyvenime. Kiekvienas žmogus per visą savo gyvenimą atlieka daug socialinių vaidmenų, kurių kaita koreguoja žmogaus gyvenimo ritmą ir dienotvarkę, tarsi atsiranda daugiau laisvo laiko ir atrodytų, kad šiuo laikotarpiu galima užsiimti mègstama, malonumo teikiančia veikla [7]. Parkinsono liga - lètinè, progresuojanti liga, kuri anksčiau ar vèliau sutrikdo kasdieninę gyvenimo veiklą ir sukelia neigalumą. Žmogus, susirgęs jaunesniame amžiuje, po kelerių metų netenka darbingumo, vyresniems asmenims prireikia artimujų pagalbos ir priežiūros, o ligai progresuojant visiems reikalinga slauga [8].

Daugelis tyrinètojų atskleide, kad asmenys, sergantys Parkinsono liga, susiduria ne tik su fizinès sveikatos, bet ir psichinès sveikatos problemomis. Sergantieji Parkinsono liga kenčia nuo depresijos, nerimo, apatijos, kognityvinių sutrikimų, demencijos, nuotaikų svyravimo. Tai turi įtakos ir gyvenimo kokybei, nes liga turi santykių problemų tiek šeimoje, tiek už šei- 
mos ribų, ligoniai linkę i vienišumą ir izoliaciją $[1,6]$.

Ligos įveikos procese kiekvienam asmeniui svarbu neprarasti savo tapatumo. Tapatumo išsaugojimui ir naujo identiteto kūrimui ligos kontekste labai svarbi tampa veikla. Žmogaus laiko naudojimas skirstomas ị keturias, laikomas fundamentaliai skirtingomis, laiko kategorijas: t.y. apmokamą darbą, neapmokamą darbą, rūpinimąsi savimi ir laisvalaiki [4]. Asmenys, sergantys Parkinsono liga, dažniausiai netenka darbinès veiklos ir jiems ypač svarbia tampa rūpinimosi savimi ir laisvalaikio veikla. Asmeniui svarbu kuo geriau pažinti save - kas patinka daryti, ką asmuo sugeba daryti geriausiai, kas yra svarbu asmeniniam gyvenimui bei santykiams su supančiais žmonèmis. Ligos ịveikos procese kiekvienam asmeniui ypač svarbu žinoti savo asmenybès bruožus, interesus, vertybes, kompetencijas. Tai sudaro galimybes išryškinti savo stipriąsias asmenybès puses [8].

Savęs pažinimas ir pozityvus savęs vertinimas yra aktyvios veiklos prielaida [7]. Socialiniuose moksluose rekreacijos procesas (organizuoto laisvalaikio veiklos) siejamas su socialine įtrauktimi: rekreacinès veiklos padeda ịgalinti žmogų spręsti savo problemas, adaptuotis visuomeninèje veikloje, ,valdyti“ savo gyvenimą, būti aktyviam visuomenès nariui [4]. Laisvalaikio veiklos yra asmens tapatybę formuojantis veiksnys, skiriami du jo aspektai: jègų atgavimas (atsipalaidavimas) ir kognityvinis (naujų dalykų mokymasis) [9] .

Laisvalaikio ịprasminimas, jo vertybès bei funkcijų supratimas yra visuomeneje pakankamai standartizuoti ir priklauso nuo jos politinès ideologijos, industrializacijos laipsnio, ekonomikos, religinès bei kultūrinès tradicijos konteksto [4]. Ivairios organizacijos, vienijančios tam tikra liga sergančius žmones, pasiūlo jiems organizuotas veiklas, suteikiančias galimybes pažinti save, plèsti socialinius ryšius, geriau pažinti ligą, realizuoti kūrybinius sumanymus. Asmenys, priklausantys draugijoms, turi galimybę patirti prasmingo laiko leidimo džiaugsmą. Viena iš organizuotų veiklų formų - dailès terapija. Dailès terapija yra meno terapijos forma, kurioje svarbiausias yra kūrybinis procesas, padedantis išreikšti save, kontroliuoti savo elgesį, stabilizuoti emocinę būseną, sumažinti stresą, pagerinti savijautą. Dailès terapija turi didelę naudą žmogui, negebančiam savęs, savo minčių išreikšti žodžiais, dailè yra puiki priemonè tai padaryti neverbaliai. Tai puikus būdas norint klientui padèti išsigydyti nuo emocinių ir psichinių traumų, patirtų negatyvių išgyvenimų [2].

Straipsnio tikslas - atskleisti organizuotos veiklos, taikant dailès terapijos elementus, naudingumą Parkinsono liga sergantiems asmenims.

Tyrimo objektas ir metodika

Siekiant atskleisti organizuotos veiklos naudingumą
Parkinsono liga sergantiems asmenims, buvo atliktas fenomenologinis kokybinis tyrimas, padedantis atskleisti realybę tokią, kokią ją mato tiriamieji.

Tyrime dalyvavo 50 - 85 metų amžiaus 23 asmenys (12 moteru ir 11 vyrų), lankantys Kauno apskrities Parkinsono draugijos Kauno skyriaus veiklas. Tyrimo dalyviai dalyvavo interaktyviuose seminaruose, kuriuose buvo taikomi dailès terapijos metodai. Interaktyvūs seminarai vyko Kauno kolegijos finansuojamos mokslo taikomosios veiklos „Idejjos praktiškai“ projekto „Parkinsono liga sergančių asmenų gyvenimo kokybės gerinimas fiziniu ir psichosocialiniu požiūriu“" metu. Tyrimo patikimumą lèmé trianguliacijos ir saturacijos principų taikymas. Tyrimo metu buvo taikoma trianguliacija pagal duomenų rinkimo instrumentus. Duomenys buvo renkami naudojant šiuos duomenų rinkimo instrumentus: neformalų grupinį interviu, stebejjimą ir dalyvaujantị stebejjimą. Tyrimo duomenys buvo renkami $2017 \mathrm{~m}$. sausio vasario mènesị. Vèliau tyrimo duomenys buvo analizuojami: išskiriami kodai, kategorijos ir analitiniai memos. Tyrimo rezultatų interpretacijai naudojamos Egzistencinès socialinio darbo teorijos nuostatos.

Atliekant tyrimą buvo laikomasi tyrimo etikos principų. Tyrimo dalyviams buvo suteikta informacija apie tyrimą. Visų tyrime dalyvaujančių asmenų vardai buvo keičiami, siekiant išsaugoti konfidencialumą.

\section{Tyrimo rezultatai ir interpretacijos}

Egzistenciné filosofija padeda asmeniui ịsisąmoninti ir atrasti savo gyvenimo prasmingumą, atskleisti savo būtị. Būties pasaulyje yra trys esminiai dalykai - išorès pasaulis (aplinka), buvimas su kitais žmonèmis ir savas pasaulis (žmogus - unikali asmenybė) [3]. Tyrimo rezultatų analizė atskleidé šias kategorijas, atspindinčias savą pasauli (žmogus - unikali asmenybè): savęs ir kitų pažinimas; pasitikèjimas savimi ir ị(si)galinimas. Buvimą su kitais žmonèmis atskleidé šias kategorijos: bendrystė su kitais ir bendravimas, bendradarbiavimas; palaikymas ir parama. Išorès pasauli (aplinką) atspindinčios kategorijos: dienos struktūra ir prasmingas laikas; teigiamų emocijų patyrimas ir naujovių išbandymas saugioje aplinkoje; pozityvus požiūris/pozityvumo skatinimas ir bendros grupès istorijos kūrimas. Egzistencinis požiūris daugeliu atvejų padeda lètine liga sergančiam asmeniui priimti besikeičiančią realybę, ǐžvelgti gyvenimo prasmę ir surasti jègų keisti gyvenimo stilių pagal kintančią sveikatos būklę.

Savęs ir kitų pažinimas. Dalyvavimas užsièmimuose, kuriuose buvo taikomi dailès terapijos elementai, sudare galimybę tyrimo dalyviams pažinti naujus grupès narius, su kuriais ateityje bus užmezgami prasmingi socialiniai ryšiai $<\ldots>$ man praejusị karta irgi labai patiko, kadangi plačiau 
susipažinome su tais, kurie atëjo pirma karta <... [J.M.].

Nors grupès nariams svarbus buvimo grupeje bendrumas, vis dèlto kiekvienas grupès narys yra unikalus, todèl labai svarbu, kad grupé priimtų kiekvieno nario individualumą. Tai prielaida kiekvienam grupès nariui pletoti savo autentiškumą. Tyrimo taikytų dailès terapijos metodų metu atsiskleide, kad grupès nariai prièmè ir palaikè kiekvieno asmens individualius skirtumus.

Kiekvienas mato kitaip (apie piešinio interpretacija). Kiekvienas dailininkas... ir tik jis supranta (ka norejo pavaizduoti), o kitas žmogus gali ir nesuprasti. [A.M.].

Vienu žodžiu, čia vanduo labai gražus. Debesys matyti. Čia žmogus èjo miško keliu. Čia miškas. Pavasarị daug gélyčiu. Ir žmogus èjo, èjo....Čia gyvena toks kaimynas. Čia toks raudonu plytu takutis. O čia ežeras, prie ežero auga meldai, pavasarị labai gražiai raudonai pražydo. O čia atbègo kiaule (visi kas klauso juokiasi). Čia E.V. laiko raketę, dešine ranka, aišku [O.M]

Šios grupelès nariai nebijojo būti kitokie, nestandartiniai tiek piešdami, tiek pateikdami piešinio interpretaciją. Simboliai, atspindintys jų kitoniškumą: raudoni meldai, raudonu plytu takas, besigananti laukuose kiaule.

Man patiko tai, kad mes gyvenom ir dirbom savo darbuose, bet dabar dauguma nebedirba, susidare mums didelis ratas, naujos pažintys, naujų žmoniu pažinimas teikia mums visiems sveikatos [G.M.].

Noriu prisijungti prie visu kalbu. Tikrai labai patiko, labai patiko visas bendravimas ir kad niekas nekritikavo, kad visi reiškè savo nuomonę, mintis ir papildè vienas kita, ir nebuvo tokiu, kaip sakoma, tu blogas, tu geras. Ir labai labai linkiu visiems grižti i jaunystę, nes tik jauni, maži vaikai atskleidžia visus savo vidinius polékius, visus savo norus ir sèkmés [P.V.].

Šių dviejų informantų pasisakymai patvirtina asmens, sergančio Parkinsono liga, tapatumo formavimą per iš naujo padarytas įžvalgas apie save. Susirgus lètine liga tarsi sugriūva anksčiau turètas asmens tapatumas, jị reikia iš naujo sukonstruoti prisimenant ir praeiti. Praeityje igytus tapatumo ženklus svarbu integruoti ị dabartinę asmens realybę ir konstruoti naują tapatumą.

Pasitikẻjimas savimi ir ị(si)galinimas. Savęs pažinimas yra savivertès didejimo prielaida, padedanti formuotis pasitikèjimui savimi. $<\ldots>$ aš tikiuosi, kad mes išeiname iš čia labiau pasitikintys savimi, ne tikiuosi, bet iš tiesu taip yra [I.M.]. Šis informantès sakinys atskleidžia grupinès veiklos, taikant dailès terapijos elementus, prasmę ir naudingumą igyti daugiau pasitikejimo savimi.

$<\ldots>$ linkiu visiems kuo dangiau judèti, nežiūrèti labai ilgai televizoriaus, na, ir visiems linkiu gerejjančios sveikatos $<\ldots>$ [E.V.]. Informanto žodžiuose atsispindi noras, siekis igalinti savo grupès draugus veiklai, kuri būtų naudinga jų psichinès ir fizinès sveikatos būklei.

$<\ldots .>$ kai čia ateini, liga tarsi išnyksta, pasijunti toks sveikas " <... $>$ [L.V.]. Užsièmimai padeda žmonèms atrasti ir pamatyti kitus dalykus, nesusikoncentruoti tik ị ligą, o daryti tai, ką dar galima padaryti. Užsièmimai tarsi įgalina dalyvius.

Kaip pažymi tyrimo dalyvè A.M. $<\ldots>$ čia viska galiu daryti $<\ldots>$. Informantès vartojamas žodis, ,galiu“ atskleidžia ịsigalinimą, gautą per grupinę veiklą. İsigalinimas leidžia asmeniui, sergančiam lètine liga, pajusti, patirti, kad jis gali kažką prasmingo ir vertingo veikti, atrasti ir priimti kitus socialinius vaidmenis, ne tik ankstesni ligonio vaidmenị. Anksčiau, prieš susirgdami, dalyviai buvo aktyvūs visuomenès nariai, turejo darbus, pomėgius, kas leido jiems užimti vertingo visuomenès nario statusą. Susirgus ir netekus šio statuso ir nuvertinant save, kaip visiškai nevertingą tik ligoni - svarbu vẻl atstatyti žmogaus vertingumą, leisti pajusti, patirti ir patikèti, kad asmuo gali būti vertinamas. Svarbiausias pirmasis žingsnis - kad sergantysis pirmiausia patikètų savimi - ịsigalintų.

Bendrystė su kitais ir bendravimas, bendradarbiavimas. Savęs pažinimas ir ịsigalinimas suteikia galimybę kitam žingsniui - bendrystei su kitais: $<\ldots>$ praejjusị karta buvau, man labai patiko tas bendravimas, toks nuoširdus $<\ldots>$ [J.V.]. Informantas grupinių užsièmimų naudingumą patiria per bendravimą. Bendravimas patenkina dalyvių priklausymo grupei poreiki, jie jaučiasi išklausyti $<\ldots>$ man patiko anąsyk, atejjau ir šiandien <...> [H.M.]. Iš šių žodžių galima speti, kad grupe išpildo tyrimo dalyvès lūkesčius patirti geras, teigiamas emocijas.

Mane truputèli stebina, gal nestebina, labai nuoširdus bendravimas ir čia labai malonu [J.M.]. Ši tyrimo dalyvė centrą pradèjo lankyti neseniai - tik antras užsièmimas, ir jau po antro ji jaučiasi grupejje priimta. Iš žodžio ,stebina “ galima daryti prielaidą, kad informanté nesitikejo taip greitai pritapti grupejje. Jau antrojo užsièmimo metu ji jaučiasi „sava“", du kartus pakartojamas žodelis ,labai““ atspindi jos geros vidinès būsenos tikrumą.

$<\ldots .>$ labai malonu, kad dar galiu ateiti $<\ldots>$ [L.V.]. $<\ldots>$ praeita karta patiko, sudomino labai. Smagu apskritai, ir šiandien žinau, kad reikès ateiti < ..> [E.V.]. Iš informantų žodžiu jaučiamas džiaugsmas, kuris prasideda dar ruošiantis ateiti ị grupés užsièmimą. Galima daryti prielaidą, kad ta savaitès diena, kai ateinama ị užsièmimą, tampa prasminga. Vien tik žinojimas, kad vyks grupès užsièmimas, suteikia smagias emocijas ,smagu apskritai girdèti“.

$<\ldots>$ praejjusị karta nebuvau, bet namuose visa širdimi buvau su jumis. Stengiuosi čia ateiti, nes žinau, kad čia labai smagu, labai gerai. Stengsiuosi büt, ateit, kiek tik galèsiu. 
Ir visiems linkiu to paties $<\ldots>>$ [D.M.]. Iš tyrimo dalyvės žodžių jaučiasi liūdesys, kad kartą negalèjo dalyvauti užsièmime. Jos žodžiai ,, visa širdimi buvau su jumis “ parodo, kad grupès užsièmimai jai labai reikšmingi, neateidama i juos tyrimo dalyvè galvoja apie tai, ko neteko. Informantès žodžiai , stengiuosi ateiti “ atskleidžia jos didelį norą, pasiryžimą dalyvauti grupès užsièmimuose, kuriuose ji patiria teigiamas emocijas „čia labai smagu, labai gerai“. Informante tarsi perkelia asmenini džiaugsmo patyrimą ir kitiems grupės dalyviams, tarsi linki, kad gerų, teigiamų emocijų patirtų ir kiti grupés nariai.

$<\ldots>$ labai patiko praejusị syki, džiangiuosi, kad gražiai pabendravome $<\ldots>$ ir humoro čia yra, patiko, labai smagiai jaučiuosi $<\ldots>$ [A.M.]. Informantei dideli džiaugsmą teikia bendravimas, kuris yra ịvairiapusis, tai suteikia smagumo jausmą.

Bendravimas ir bendradarbiavimas padeda jaustis naudingiems vieni kitiems, tai padidina motyvaciją dalyvauti užsièmimuose ir suteikia jausmą, kad grupès narių dalyvavimas svarbus vieni kitiems.

Palaikymas ir parama vienas kitam. Dalyvaujant organizuotoje veikloje, taikant dailès terapijos elementus, kuriami ir plètojami socialiniai ryšiai, suteikiama galimybė gilesnèms sąveikoms tarp grupès narių.

Aš praejjusị karta nebuvau, bet buvo daktarè, ji sakè, kad buvo labai ịdomu, šiandien abejojau eiti ar ne. Bet galvoju, kad eisiu, tikrai neslidu. Taip pat pasakojo, kad labai ịdomu buvo, tai negalèsiu neateiti [J.M.]

Praejjusị karta nebuvau, negalejjau ir labai ačiū D.M., kad man skambino ir priminè. Labai dèkoju visam šitam kolektyvui, kurie rūpinasi, visi draugiški. Aš labai patenkinta, kad atëjau, kad D.M. man primine, linkiu optimizmo [A.M.].

Tyrimo dalyviai vienas kitam perduoda informaciją, dalijasi patyrimais ir išgyvenimais, palaiko vieni kitus, paskatina (net įgalina) vieni kitus dalyvauti užsièmimuose. Informančiu citatos atskleidžia stiprų pasitikejimą grupès dalyviais, su kuriais yra užsimezgę asmeniniai ryšiai. Skambučiai ir priminimai vieni kitiems neleidžia nedalyvavusiam užsièmime pasijusti pamirštam ir vienišam. Priešingai - užsièmime nedalyvavęs asmuo yra prisimenamas, įtraukiamas.

Grupès nariai teikia vienas kitam palaikymą. Palaikymas svarbus elementas asmeniui, kuris nedrịsta ịsitraukti į naujas veiklas: <.. > čia gali būti labai sudètinga papasakoti (apie nupiešta piešini), labai atsiprašau, jei mano kalba bus nerišli < ...> [H.M.]. Tyrimo dalyviai, išgirdę tokius žodžius, iš karto nuramino moterị, kad labai stengsis klausyti, o jei ko nesupras - paklaus.

Piešt prireikè, o aš gyvenime nesu piešęs [A.V.] (pasisakantis dalyvis juokiasi, visa grupe ploja). Refleksijos metu tyrimo dalyvis nebijo pripažinti savo negebejimų, tuo pačiu metu gauna grịžtamaji ryšį ir palaikymą iš grupès - plojimus, reiškiančius padrąsinimą.

Buvo gera nuotaika. Tiesiog jautiesi kažkaip pakylètas. Ačiū visiems už tai [V.V.] - Šis dalyvis suvokia, kad gera nuotaika, atmosfera buvo sukurta tik pačių grupès narių dėka, todèl šis dalyvis išgyvenęs ypatingą jausmą - pakylejjimą yra dèkingas visai grupei.

Po kiekvienos grupelès (kiekviena piešè atskirus piešinius) piešinio pristatymo ir interpretacijos aidejo plojimai. Vieni kitu labai atidžiai klausèsi, uždavinèjo klausimus, reagavo, vis skatino daugiau kalbèti sakydami vieni kitiems pagyrimus (stebèjimas). Plojimai ir pagyrimai vieni kitiems atspindi šiltą, palaikančią atmosferą grupejje, padedančią sergančiam Parkinsono liga plètoti savo turimus gebejjimus.

Dienos struktūra ir prasmingas laikas. Kiekvienam asmeniui svarbu įprasminti savo buvimą pasaulyje, o dalyvaujant organizuotoje grupineje veikloje lengviau suteikti kiekvienai dienai prasmę.

$<$ _..> jeigu čia būtų blogai, tai per tokị slidu ora, drègna, tiek daug čia nesusirinktu. Vadinasi, čia tikrai labai gerai. Ir tikrai gerai: atsipalaiduojam, išeinam iš namu. Man atrodo, kad visi eisim ir kol dar leis galimybès, na visi eisim su malonити $<\ldots>$ [J.M.]. Informantès pateiktuose samprotavimuose atsiskleidžia grupès veiklos naudingumas. Tyrimo dalyvès nuomone, jei grupè susirenka ir esant sudètingoms oro sąlygoms, tai tiesiogiai atspindi grupès narių pasitenkinimą vykstančia veikla ir procesu. Grupinio proceso metu ši tyrimo dalyvė patiria atsipalaidavimą, tarsi palikdama visus rūpesčius už grupès ribų. ,Išèjimas iš namu “ informantei savaime yra vertingas, suteikia vienai konkrečiai dienai prasmingą tikslą. Tyrimo dalyvès pasisakyme yra vartojama ,mes “ forma. Galima numanyti, jog informante tiki, kad taip jaučiasi ne tik ji, bet ir kiti grupès nariai.

Labai svarbi grupès veikla - refleksijos - pasidalinimas asmeninèmis įžvalgomis po įvykusios veiklos: < ..> sédedama šitam rate, aš dabar supratau, kodèl mes nupiešèm didelę saulę. Pažvelkite - tai liečia mus visus. Ačiū. <..> [H.M.]. Tyrimo dalyvè labai taikliai piešinio simboli - saulę - sulygina su visa grupe. Šis simbolis atspindi grupès jaukumą, šilumą, rūpestị vienų kitais. Refleksija šiai dalyvei buvo ypač svarbi, nes tik refleksijos metu $<\ldots>$ dabar a ̌ supratau $<\ldots>$ padaro tokias svarbias įžvalgas.

Patiko kompanija prie stalo, kadangi aš nemoku piešti ir nenoriu, tai pats bendravimas labai malonus su žmonemis, pasijuokti vienas iš kito [L.V.]. Moteris nebijo būti atvira su grupès nariais, ji atvirai pasako, kokių veiklų ji nenori. Tačiau tuo pačiu metu atranda būdą, kaip dalyvauti toje veikloje - ji mègaujasi tiesiog grupès procesu - bendravimu ir ji lydinčiu humoru.

Teigiamų emocijų patyrimas ir naujovių išbandy- 
mas saugioje aplinkoje. Organizuotoje grupinèje veikloje, kurioje taikomi dailès terapijos elementai, yra galimybè išgyventi ir patirti naujų potyrių, kurių paprastai kasdieniame gyvenime asmuo nedrịstų ar nenorètu išbandyti.

Džiaugiuosi, man gera šitam rate. [I.M.]. Čia atsispindi I.M. emocinè būsena, lankant grupinius užsièmimus ,man gera".

$<\ldots>$ labai smagu ir iš savęs pasijuokti $<\ldots>,<\ldots>$ čia žinot, kaip smagu, labai daug šypsenos. Pati iš savęs pasijuokti $<\ldots>,<\ldots>$ saule labai madinga, išsidažiusi $<\ldots>$ (visi juokiasi, pastebejjimas apie grupès nupiešta saule). $<$...galèsime ir namuose tapyti < ..> (visi juokiasi).

Užsièmimuose dalyviai turèjo galimybę išbandyti naujas veiklas. Tyrimo dalyviams buvo taikyti dailès terapijos metodai, kurie jiems pakankamai nauji.

$<\ldots>$ va, kaip gražiai padarète. Labai gražios gèlès (nupieštos). $<\ldots>$ [L.M.].

$<\ldots>$ Ant melsvo ežero bangu plaukiojo laivelis (Vienas dalyvis apie nupiešta popieriaus lape ežera; dalyvio veide šviečia šypsena, jaučiasi pasididžiavimas, kad prisimena mokyklos laiku eilèrašti). Labai gražiai pasakète (sureaguoja kitas dalyvis) < ..> [A.V.] < ..> padeklamuokite, jūs mokate deklamuoti <...> (dar prašo pasakyti eilèraščiu).

$<\ldots>$ Saulè šviečia, čia tikrai pas mus gražu! <..>. (Dalyve apie nupiešta saulę piešinyje; piešinys tema-Pavasaris). $<\ldots>$ Man atrodo, kad visai gerai gavosi $<\ldots>$ (dalyve apie nupiešta bendra piešini) $<\ldots>$ labai gražu $<\ldots>$ (dalyve apie nupiešta bendra piešini).

Nauji darbo būdai, metodai, idèjos visada žmonèms kelia ịtampą. Grupés nariai dailès terapijos metodus išbande pirmą kartą. Išbandydami naujus dalykus, proceso metu jie palaiké vienas kitą. Pagyrimai yra paskatinimas tęsti pradètą veiklą, užbaigti ir iki galo atlikti užduotị.

$<\ldots>$ kas pratęsia piešinị? < ..>. Iš šio dalyvio pasisakymo galima spèti, kad grupès narių tarpusavio santykiuose nèra konkurencijos, vyrauja vienas kito palaikymas.

$<\ldots>$ piešimas labai padeda nusiraminti $<\ldots>$ [J.M.]. Dalyviai padeda vieni kitiems atrasti naujos, neišbandytos veiklos prasmę. Igarsinimas žodžiais pasiekia kitus dalyvius, padeda ir jiems iprasminti tą veiklą, kurią atlieka čia ir dabar.

$<\ldots$ galesime ir namuose tapyti $<\ldots>$ (visi juokiasi) Nors ši citata nuskambejjo kaip juokas, vis tik joje galima ižzvelgti savęs ịgalinimą - daryti naujas, neịprastas, neišbandytas veiklas gyvenime. Tai reiškia ir baimès nugalèjimą (baimès jausmo imtis naujų veiklų sumažejimą).

Ir mes taip pat kviečiam visus, kad namuose pieštumèm. Mes labai norim ir namuose piešti. Užsikrèsti jaunyste, energija ir viskuo [L.M.] - dalyvio pasisakyme atkreiptinas dèmesys į vartojamus žodị „,mes“. Naujų veiklų išbandymas tarsi buvimas savo vidumi jaunam, kai kaip tik norisi iš- bandyti viską, kas yra nepažinta „<..> užsikrèsti jaunyste, energija ir viskuo".

Iš vienos grupès veiklos gali gimti iniciatyvos ir kitoms veikloms, kurios yra naujos, netikètos, nebandytos:

$<\ldots>$ kadangi aš esu siuvinejjusi, tai galèčiau išsiuvinèti kiekvienam po raudona tulpe < ...> [J.M.].

$<\ldots>$ mes pavasarị važiuosim i botanikos soda $<\ldots>$ [B.M.].

$<\ldots>$ kita karta dainuosim $<\ldots>$ [G.M.].

Kiek išryškejjo talentų. Visi gal neįtarèm, kad mes taip mokam, taip sugebam. O va, kaip gražiai pakomentavom, taip nupiešèm, visa istorija išèjo [V.M.].

Noriu prisijungti prie visu kalbų. Tikrai labai patiko, labai patiko visas bendravimas ir kad niekas nekritikavo, kad visi reiškè savo nuomone, mintis ir papildè vienas kita, ir nebuvo tokiu, kaip sakoma, tu blogas, tu geras. Ir labai labai linkiu visiems grįžti i jaunystę, nes tik jauni, maži vaikai atskleidžia visus savo vidinius polèkius, visus savo norus [V.V.].

Apibendrinant tyrimo dalyvių mintis, galima teigti, kad naujovių išbandymas saugioje aplinkoje sudare galimybes tyrimo dalyviams atrasti savo turimus gebejjimus, pomègius, talentus ir paskatino išdrịsti ịsitraukti ị naujas, nebandytas veiklas.

Pozityvus požiūris ir bendros grupès istorijos kūrimas. Bendri užsièmimai, veikla padeda grupès nariams atrasti daug pozityvaus požiūrio ị gyvenimą. Lètine liga sergantis asmuo gali turèti negatyvų požiūrị ị supantị pasaulị, nerasti jame prasmès ir džiuginančių dalykų, o tai gali turèti ịtakos tokiai emocinei būsenai kaip depresija, nuolatinis nerimas ir pan. Taikant dailès terapijos metodus išryškèjo, kad grupès nariai turi daug vidinio pozityvumo, kuriuo dalijasi vieni su kitais.

Norim saulès. Ir kad daug būtu, šviestu. Paskui gèlytès pražydo, žolytè, medelis. Čia dar zuikelis Velyku ieško. Na, čia labai gražūs varliukai. Labai gražios gèlytès: čia piené, rožè, tulpé. (grupés pasakojimas apie savo piešini).

Iš grupès narių pasakojimo atsispindi pozityvaus požiūrio ị supančią aplinką simboliai: saulè, ịvairios gèlès (ypač tulpé - Parkinsono draugijos simbolis).

Kiekviena grupe turi savo istoriją. Išgyventos, išjaustos, išreflektuotos patirtys vienija grupès narius, tai yra grupès identitetas. Taikant dailès terapijos metodus, asmenys taip pat kūrè bendro piešinio interpretacijas, remdamiesi bendra grupès istorine patirtimi:

Pradejom mes gyventi prie Nemuno. Mes prie Nemuno užaugom, mūsu miestas Kaunas ir tada mūsu Nemunèlis teka čia pro Balbieriškio kilpa, toliau niūniuoja. Pavasaris prasideda. Kažkas daržoves augina: čia morkos, čia salotos. Pavasaris prasideda pirmiausia lietumi (visa piešini pristatanti grupé pradeda trypti kojomis), nuplauna po žiemos 
visus nešvarumus. Tada jau pradeda žydèti mūsu gèlytès. Čia sužydi tulpès, toliau žydi žibuoklès, čia mūsu miniatiūrinès žibuokles. Čia visos pavasarinès gèlès. Parskrido varnènas (kažkas mègdžioja varnèna) (visa grupe juokiasi). Varnènas renka visus šapelius ir kirminus. Taip pat prie Nemuno atejo pasivaikščioti šunelis, jaunuolis su šuneliu ir džiangiasi gamta kartu su mumis.

Iš grupès narių pasakojimo galima ịžvelgti bendrus grupès istorijos elementus. Svarbus vartojamas žodis ,"mūsu““. Labai įdomu, kad kurdama pasakojimą grupelè nebijojo improvizuoti, nupieštus dailès terapijos simbolius papildẻ naujais komponentais - garsais - kurių nereikalavo užduoties formuluotè. Tai rodo grupès narių kūrybiškumą. Kūrybiškumas, kaip savybè, yra labai svarbus ir kasdienineje veikloje, ypač asmeniui, sergančiam lètine liga, kai ị daugelị situacijų gyvenime tenka reaguoti kitaip, t.y. kūrybiškai.

\section{Išvados}

1. Organizuota veikla, taikant dailès terapijos elementus, sudaro galimybes Parkinsono liga sergantiems asmenims atrasti, plètoti ir stiprinti savo identitetą per gilesnị savęs bei kitų pažinimą ir į(si)galinimą. Sutvirtèjęs/suformuotas identitetas leidžia asmeniui pasijausti vertingu grupès nariu bei padidina ịgalinimo tikimybę.

2. Tyrimas atskleidè, kad organizuotos grupès nariams labai svarbus buvimo grupejje bendrumas, tačiau drauge kiekvienas grupès narys savo gyvenimo istorija yra unikalus. Bendros veiklos sèkmei labai svarbus priimti kiekvieno grupès nario individualumą.

3. Organizuotos veiklos, taikant dailès terapijos elementus, naudingumas išryškèjo pasitikèjimo augimo, igalinimo (ịsigalinimo), socialinių ryšių kūrimo ir plètojimo, dienos struktūros formavimo bei prasmingo laiko leidimo, teigiamų emocijų patyrimo, naujovių išbandymo saugioje aplinkoje, pozityvaus požiūrio skatinimo, bendros grupès istorijos kūrimo srityse. Ypatinga organizuotos veiklos nauda reiškèsi kūrybiškai išbandant naujas veiklas saugioje aplinkoje bei bendros grupès istorijos kūrimo procese.

\section{Literatūra}

1. Bouwmans A, Weber W. Neurologist's diagnostic accuracy of depression and cognitive problems in patient with parkinsonism. Bio-Med Central Neurology 2012;36:1471-2377.

2. Dawson H., Art therapy benefits for anxiety \& Stress at Work. - 2015. (žiūrèta 2017-09-12). http://www.arttherapyblog. $\mathrm{com} / \mathrm{mental}$-health/art-therapy-benefits-for-anxiety-stress-atwork/\#.V1R1kvmLTIU.

3. Grakauskaitė-Karkockienė D. Kūrybos psichologija. Vilnius. UAB Logotipas. 2002; 238.

4. Kublickienė L. Laisvalaikio sociologija: paradigmų skirtumai.
Filosofija. Sociologija, 2001; 2:35-42.

5. Lisauskienè D., Aleksienė V. Socialinis darbuotojas kaip rekreacinès veiklos organizatorius dirbantis su gatveje laiką leidžiančiais jaunais žmonėmis. Visuomenès sveikata, 2016; 2:83-91.

6. Martignoni E, Citterio A, Zangaglia R. et al. How parkinsonism influences life: the patients' point of view. Journal of the neurological scienses $2011 ; 32: 125-31$.

https://doi.org/10.1007/s10072-010-0435-x

7. Staniulienè D. Veikla ir gyvenimo būdas. Socialinè gerontologija: ištakos ir perspektyvos. Mokymo knyga / Vytauto Didžiojo universitetas. Socialinio darbo institutas. Kaunas. Vytauto Didžiojo universiteto leidykla, 2002; 336.

8. Valeikienè V. ir kt. Parkinsono liga ir neigalumas. Sveikatos mokslai, 2015;25(1):54-57.

https://doi.org/10.5200/sm-hs.2015.009

9. Žiliukaitè R., Poviliūnas A., Savicka A. Lietuvos visuomenès vertybių kaita per dvidešimt nepriklausomybės metų (monografija). Vilnius. Vilniaus universiteto leidykla, 2016; 316.

10. Žiūgždienė J. Parkinsono liga gali paliesti ir jauną žmogų. Bernardinai.lt. -2016. (žiūrèta 201709 06): http://www.bernardinai. 1t/straipsnis/2016-04-11-parkinsono-liga-gali-paliesti-ir-jauna$\mathrm{zmogu} / 142938$.

\section{THE AVAIL OF ORGANIZED ART THERAPY ACTIVITIES FOR PEOPLE WITH PARKINSON'S DISEASE}

\section{A. Kavaliauskienè, I. Venckienė}

Key words: the avail of organized activities, Parkinson's disease, art therapy, identity, empowerment, usefulnes, leisure activities.

Summary

The person's identity and lifestyle are greatly affected by changes in life in chronic illnesses. These changes cause confusion in the internal and external life of a person. Parkinson's disease is a chronic, progressive disease that sooner or later disturbs everyday life of a person and causes person's disability. It is important for every person to keep their identity in the process of coping with the illness. Activities are very important in the creation of a new identity in the context of a disease. People with Parkinson's disease usually loose their working routines, self-care and leisure activities, which are especially important for them.

Various organizations combine people with a particular illness to offer them organized activities. These activities provide them possibilities to expand self-knowledge, develop social contacts, get to know better the disease, better realize creative ideas. Those who are members of any organizations have the opportunity to experience the joy of a meaningful time permit. The aim of the article is to reveal the usefulness of organized art therapy activities for people with Parkinson's disease.

A phenomenological qualitative study was conducted. 23 people from the Kaunas Branch of Kaunas County Parkinson's Society participated in the study. The results of the study revealed that organized art therapy activities enable people with Parkinson's disease to discover, develop and strengthen their identity through 
a deeper knowledge of themselves and others. The consolidated / formed identity allows a person to feel a valuable group member and increases the possibility of empowerment. The analysis of the research data showed that the members of the organized group are very important for the group commonality but however each member of the group is unique with his life history. The individuality of each group member is very important for the success of a joint activity. According to the results of the research, the usefulness of the organized art therapy activities was found in the following areas: creation and development of social relationships, formation of daily structure and meaningful time-lapse, experience of affirmation emotions, testing of innovations in a safe environment, promotion of a positive attitude, creation of a group history story. A particular benefit of organized activities was the creative experimentation of new activities in a safe environment and in the process of creating a common history of the group.

Correspondence to: ausra.kavaliauskiene@go.kauko.lt

Gauta 2017-10-05 